\title{
ZOLEDRONIC ACID ADMINISTRATION ENHANCES FRACTURE HEALING IN THE OSTEOPOROTIC FRACTURES IN OVARIECTOMIZED RABBITS
}

\author{
Cansabuncu Gokhan, ${ }^{1}$ Sahin Namık, ${ }^{2}$ Akalin Yavuz, ${ }^{3}$ Cevik Nazan, ${ }^{3}$ Ozkaya Guven ${ }^{4}$ \\ ${ }^{1}$ Bartın State Hospital, Department of Orthopedics and Traumatology, Bartın, Turkey \\ ${ }^{2}$ Konya Research and Training Hospital, Department of Orthopedics and Traumatology, Konya, Turkey \\ ${ }^{3}$ Bursa High Research and Training Hospital, Department of Orthopedics and Traumatology Yildirim, Bursa, Turkey \\ ${ }^{4}$ Medical Faculty of Uludağ University, Bursa, Turkey
}

Primljen/Received 15. 01. 2019. god.

Abstract: Objectives: To evaluate the radiological, histological and mechanical effects on osteoporotic fracture healing of single-dose zoledronic acid (ZA) applied to an animal model with an experimentally created osteoporotic bone fracture.

Methods: A total of 14 adult, female New Zealand rabbits, aged 5-6 months were used in the study. Bone mineral density (BMD) values were calculated from bone densitometry measurements and recorded. Bilateral ovariectomy was then applied to all the rabbits. At 10 weeks after ovariectomy, bone densitometry was again performed on all the animals and the BMD values were compared. Osteoporosis was accepted as having developed in animals determined with a reduction of $28 \%$ in BMD values. After the placement of a K-wire intramedullarly in the femurs of the rabbits, a closed fracture was created with the standard method. The animals were then randomly separated into 2 groups as the zoledronic acid group (ZAG) and the control group (CG). An infusion of 0.1 $\mathrm{mg} / \mathrm{kg}$ ZA was administered to the ZAG animals from the ear vein. With visualisation of bone union rabbits were sacrificed by decapitation. Radiological, mechanical and histological assesments were then applied.

Results: In the histological evaluation, the mean histological score was determined as 5.00 in the ZAG and 3.00 in the CG. The difference between the groups was found to be statistically significant $(\mathrm{p}<0.001)$. In the radiological evaluation, the mean score was 7.00 in the ZAG and 6.25 in the CG. Even though higher points were obtained by the ZAG in the inter-observer evaluations, the difference between the groups was not statistically significant $(p=0.073)$. In the mechanical evaluation, the elasticity collapse in negative propor-
Prihvaćen/Accepted 28. 02. 2019. god.

tion to rigidity was measured as $2.91 \mathrm{~mm}$ in the ZAG and $3.96 \mathrm{~mm}$ in the $C G(p=0.686)$. The rigidity data of the ZAG were higher in the mechanical tests but the difference between the groups was not statistically significant $(\mathrm{p}=0.086)$.

Conclusion: As the results of the study showed that the ZAG had higher values than those of the $C G$ in all the histological, mechanical and radiological evaluations, the application of a single dose of ZA can be considered to increase the healing of osteoporotic fractures.

Key words: Bone healing; Osteoporosis; Ovariectomy; Zoledronic acid; Animal Model.

\section{INTRODUCTION}

Bisphosphonates, which are the most commonly used medications in the treatment of osteoporosis, inhibit bone resorption, creating an anti-catabolic effect. Zoledronic acid (ZA) is the most potent of these medications (1). Due to this anti-catabolic property, the ZA effect on bone healing has been examined in many experimental studies $(2,3,4)$. However, the healing of an osteoporotic bone is different from normal fracture healing (5). Therefore, it should be remembered that even after an excellent operation, success will be determined by the strength and quality of the newly formed bone. Although the available clinical evidence is insufficient, the slowdown in bone mechanism in osteoporosis is considered to possibly be responsible for delayed callus maturity and the retardation in bone healing (6). However, although ZA, which is frequently used in osteoporosis treatment, is known to reduce the risk of new fracture formations, its effect on fracture healing in osteoporotic patients is as yet unknown. 


\section{AIM}

The aim of the present study was to evaluate the effect of ZA, which is commonly used in the treatment of osteoporosis, on the healing of bones with osteoporotic fractures created experimentally in rabbits using radiological, histological and mechanical methods.

\section{METHODS}

14 adult female New Zealand rabbits, aged 5-6 months, were obtained from a local laboratory animal application and research center for use in the study. Approval for the study was granted by the Local Ethics Committee for Animal Research. To take the bone densitometry measurements at the beginning of the study, all the animals were administered intramuscular 40 $\mathrm{mg} / \mathrm{kg}$ ketamine hydrochloride (Ketalar, Pfizer Inc., Istanbul, Turkey) and $5 \mathrm{mg} / \mathrm{kg}$ xylazine (Rompun, Bayer Turkish Chemical Inc., Istanbul, Turkey) then positioned prone while under general anaesthesia. The device was calibrated for the animals and the $2^{\text {nd }}, 3^{\text {rd }}$ and $4^{\text {th }}$ lumbar vertebrae were scanned. The bone mineral density (BMD) values were calculated as milligram / square centimeter $\left(\mathrm{mg} / \mathrm{cm}^{2}\right)$ and recorded.

\section{First operation (Ovariectomy)}

Under general anesthesia, for surgical prophylaxis, each rabbit was injected $50 \mathrm{mg} / \mathrm{kg}$ cefazolin sodium (Sefazol, Mustafa Nevzat Medical Inc. Istanbul, Turkey) intramuscularly. The abdominal cavity was opened with a $4 \mathrm{~cm}$ laparotomy incision along the abdominal midline. After reaching the ovaries, the mesovarium and tuba uterina were ligated and ovarian tissues were bilaterally excised. After a 10-week waiting period, the presence of osteoporosis was confirmed by repeated BMD measurements showing a decrease of at least $28 \%$ from the previous values.

\section{Second operation (Intrameduller fixation)}

A vertical $3 \mathrm{~cm}$ incision was made on anterior of the knee. Medial parapatellar arthrotomy was performed to reach the joint. The patella was transferred to the lateral. The knee joint was put in flexion and a 2.5 $\mathrm{mm}$ intramedullary K-wire was advanced retrograde so as to center the femur intercondylar area from the patellofemoral joint line level. The end of the K-wire was cut off to avoid contact with the joint (Figure 1). Following the intramedullar placement of a K-wire, a standard closed fracture was applied to the femur using the the three-point technique with the device described by Bonnerans et. al (7). All procedures were applied in the laboratory while the animals were under anesthesia. The fractures produced were confirmed with standard femur antero-posterior and lateral (Shimadzu, Kyoto, Japan) radiographs taken while the animals were still anesthetized. The animals were then randomly separated into 2 groups as ZAG and CG. Animals in $\mathrm{CG}$ were administered intravenous saline placebo of $0.9 \%$ in the ear vein and the ZAG subjects were administered zoledronic acid (Zometa ${ }^{\circledR}, 4 \mathrm{mg}$ Flacon, Novartis, Istanbul, Turkey) as $0.1 \mathrm{mg} / \mathrm{kg}$ diluted in $10 \mathrm{ml}$ saline using an infusion pump over 15 minutes.

\section{Radiological Evaluation}

10 weeks after the second operation radiographic union was observed. All animals were euthanatized by decapitation. The femurs with the implants were disarticulated from the knee and hip joints. All soft tissue was

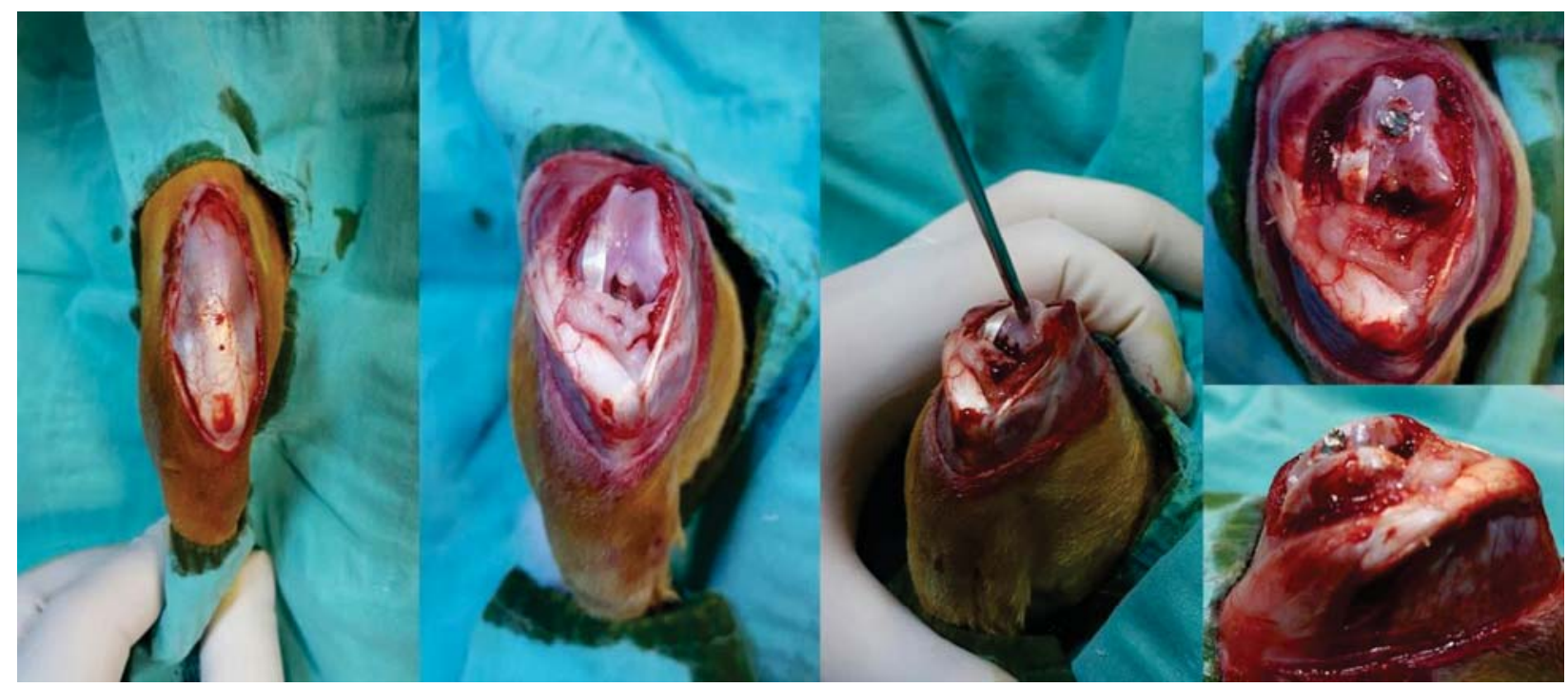

Figure 1. Incision, patellar tilt, entrance point of the implant sent for fixation into the femur and its appearance in the intramedullary canal 
removed from the bone. Union evaluation was made from 2 site radiographs using a radiological scoring system of remodelling, bone healing findings and periosteal reactions in the union area (8) (Table 1), Evaluations of the samples were made by two separate radiologists.

\section{Mechanical Tests}

4 samples were taken from each group for mechanical evaluation. K-wires were removed from the intramedullar canal before testing. In the three-point bending test, the sample was placed between two supports at $\mathrm{L}$ distance and $\mathrm{P}$ force was applied on the midpoint. A universal testing device of $250 \mathrm{kN}$ load capacity (ALERGE®, Istanbul, Turkey) was used for the test. To assess the relationship between the force and the amount of collapse at the midpoint, force was applied at $10 \mathrm{~mm} / \mathrm{minute}$ and the data of the force applied and the amount of collapse were recorded.

\section{Histological Evaluation}

Histological evaluation was applied to all samples. For histopathological examination bone tissues were cut into 2-3 mm sections using a spring-saw in order to include the callus tissues formed after the union and these then were put into the decalcification solution (Bio$\operatorname{dec} \AA$, Biooptica, Milano, Italy). We observed that bone tissues have decalcified on the sixth day. The samples were put through alcohol and xylol series with the routine automatic follow-up system (Shandon ${ }^{\circledR}$ Waltham, Massachusetts, USA), and were then embedded in paraffin blocks and cut into circular sections of 4-5 microns. Samples were stained with hematoxylin-eosin. Histological classification of healing was made in accordance with the histological healing scale defined by $\mathrm{Hu}-$ oet. al (9) (Table 2). In the $16^{\text {th }}$ week of the study, one of the subjects in the control group was lost through natural causes and was excluded from the study.
Table 1. Radiological Scoring system for fracture healing

\begin{tabular}{|c|c|}
\hline Categories & Scores \\
\hline \multicolumn{2}{|l|}{ Periosteal reaction } \\
\hline $\begin{array}{l}\text { Full } \\
\text { Moderate } \\
\text { Mild } \\
\text { None }\end{array}$ & $\begin{array}{l}3 \\
2 \\
1 \\
0\end{array}$ \\
\hline \multicolumn{2}{|l|}{ Bone Union } \\
\hline $\begin{array}{l}\text { Union } \\
\text { Moderate bridge }(>\% 50) \\
\text { Mild bridge }(<\% 50) \\
\text { Nonunion }\end{array}$ & $\begin{array}{l}3 \\
2 \\
1 \\
0\end{array}$ \\
\hline \multicolumn{2}{|l|}{ Remodeling } \\
\hline $\begin{array}{l}\text { Full remodeling cortex } \\
\text { Intramedullary canal } \\
\text { No remodeling }\end{array}$ & $\begin{array}{l}2 \\
1 \\
0\end{array}$ \\
\hline Maximum total score & 8 \\
\hline
\end{tabular}

\section{Statistical Evaluation}

Statistical data analysis was carried out using SPSS 22.0 software. Conformity of the data to normal distribution was evaluated with the Shapiro-Wilktest. For the non-normally distributed data, the Mann-Whitney $U$ test was used to compare two groups. In the comparison of dependent groups, the Paired Samples t-test was applied to normally distributed data. The interclass correlation coefficient was used to determine inter-rater reliability. The level of statistical significance was accepted as $\alpha=0.05$.

\section{RESULTS}

In bone densitomentry, pre-ovariectomy mean BMD value was found $354 \pm 16 \mathrm{mg} / \mathrm{cm}^{2}$. At 10 weeks after ovariectomy, bone densitometry was again performed

Table 2. Histological evaluation scale for fracture healing histological state

\begin{tabular}{|l|c|}
\hline Histological State & Score \\
\hline Mature (lamellar) bone & 10 \\
\hline Immature bone and small amount of mature bone & 9 \\
\hline Completely immature (woven) bone present & 8 \\
\hline Mostly immature bone and little cartilage present & 7 \\
\hline Cartilage and immature bone of equal amounts & 6 \\
\hline Mostly cartilage and small amount of immature (woven) bone & 5 \\
\hline Cartilage tissue present & 4 \\
\hline Fibrous tissue and cartilage tissue of equal amounts & 3 \\
\hline Mostly fibrous tissue and small amount of cartilage tissue & 2 \\
\hline Fibrous tissue is present in the callus tissue of the histological section examined & 1 \\
\hline
\end{tabular}


and mean BMD value found as $255 \pm 25 \mathrm{mg} / \mathrm{cm}^{2} .28 \%$ fall was observed between the initial BMD values of the rabbits and the BMD values at the $10^{\text {th }}$ week following the ovariectomy. These changes between the preoperative and postoperative $10^{\text {th }}$ week data were found to be statistically significant $(\mathrm{p}<0.001)$.

For the radiological evaluation, the radiographs taken at 10 weeks after the formation of the fracture (Figure 2) were scored by 2 independent observers using the previously-mentioned scoring system.

Inter-rater reliability was found to be high at the end of the scorings ( $\mathrm{ICC}=0.908 ; 95 \% \mathrm{CI}(0.737-0.970)$ ). Although the ZAG scores were higher than those of CG, the statistical analyses showed no significant difference between the groups $(p=0.073)$ (Table 3 ).

Following the mechanical evaluation the change in the load applied in relation to the amount of collapse in the CG samples and the values obtained are presented in Table 4. This table also shows the results concerning rigidity. When these results were assessed statistically, the differences between the groups were not found to be significant $(\mathrm{p}=0.086)$.

In the histological evaluations, a large amount of connective tissue and newly formed capillary vessels

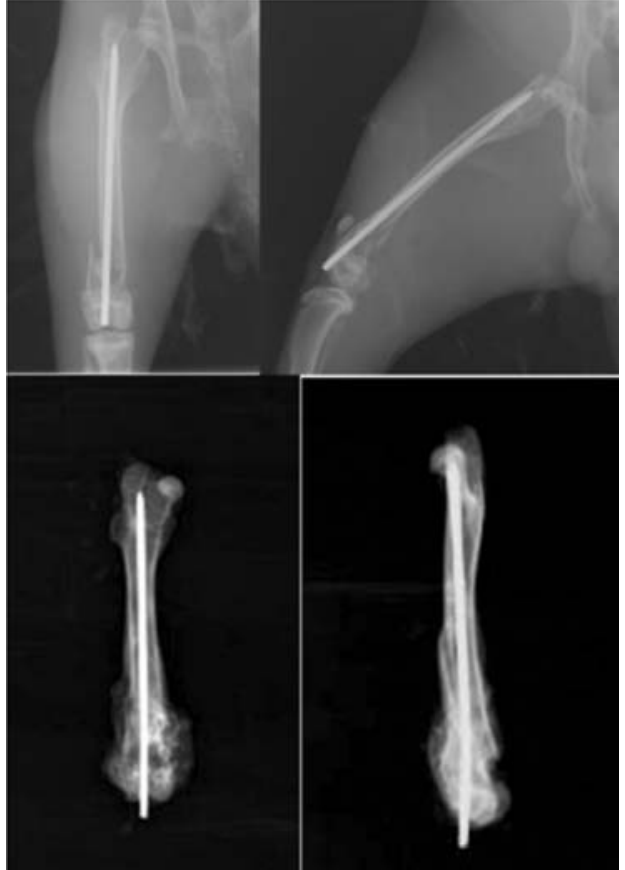

Figure 2. The view of anteroposterior and lateral radiographs of closed fractures that were created by standard methods and the view of bone union after 10 weeks

Table 3. Bone healing values of the groups

\begin{tabular}{|c|c|c|c|c|c|c|c|}
\hline \multicolumn{4}{|c|}{ Control Group } & \multicolumn{4}{|c|}{ Zoledronicacid group } \\
\hline & Observer 1 & Observer 2 & Mean & & Observer 1 & Observer 2 & Mean \\
\hline Sample 1 & 3 & 4 & 3.5 & Sample 1 & 7 & 7 & 7 \\
\hline Sample 2 & 6 & 6 & 6 & Sample 2 & 6 & 6 & 6 \\
\hline Sample 3 & 7 & 7 & 7 & Sample 3 & 8 & 8 & 8 \\
\hline Sample 4 & 6 & 6 & 6 & Sample 4 & 7 & 7 & 7 \\
\hline Sample 5 & 7 & 6 & 6.5 & Sample 5 & 8 & 7 & 7.5 \\
\hline Sample 6 & 7 & 7 & 7 & Sample 6 & 7 & 7 & 7 \\
\hline Sample 7 & - & - & - & Sample 7 & 7 & 7 & 7 \\
\hline Median & & 6.25 & & Median & 7. & & $\mathbf{P}=\mathbf{0 . 0 7 3}$ \\
\hline
\end{tabular}

Table 4. Biomechanical results of the samples pertaining to control and zoledronic acid groups

\begin{tabular}{|l|c|c|c|c|}
\hline \multicolumn{1}{|c|}{ Sample name } & $\begin{array}{c}\text { Elastic force } \\
\text { (N) }\end{array}$ & $\begin{array}{c}\text { Bending Moment } \\
\text { (Nmm) }\end{array}$ & $\begin{array}{c}\text { Elastic collapse } \\
\text { (mm) }\end{array}$ & $\begin{array}{c}\text { Rigidity } \\
\text { (Nmm2) }\end{array}$ \\
\hline C1 & 304 & 7.223 & 5,38 & 1.009 .104 \\
C2 & 167 & 3.961 & 2,96 & 1.005 .347 \\
C3 & 128 & 3.029 & 2,43 & 936.652 \\
C4 & 334 & 7.505 & 4,97 & 1.019 .859 \\
\hline Mean & 235 & 5.592 & 3,96 & 1.007 .225 \\
\hline ZA 1 & 196 & 4.415 & 3,45 & 862.706 \\
ZA 2 & 216 & 4.856 & 2,37 & 1.380 .693 \\
ZA 3 & 392 & 5.739 & 6,06 & 983.428 \\
ZA 4 & 255 & 5.297 & 1,87 & 2.070 .403 \\
\hline Mean & 235 & $\mathbf{0 , 6 8 6}$ & 2,91 & 1.182 .060 \\
\hline p value & $\mathbf{0 , 6 8 6}$ & $\mathbf{0 , 6 8 6}$ & $\mathbf{0 , 8 8 6}$ \\
\hline
\end{tabular}




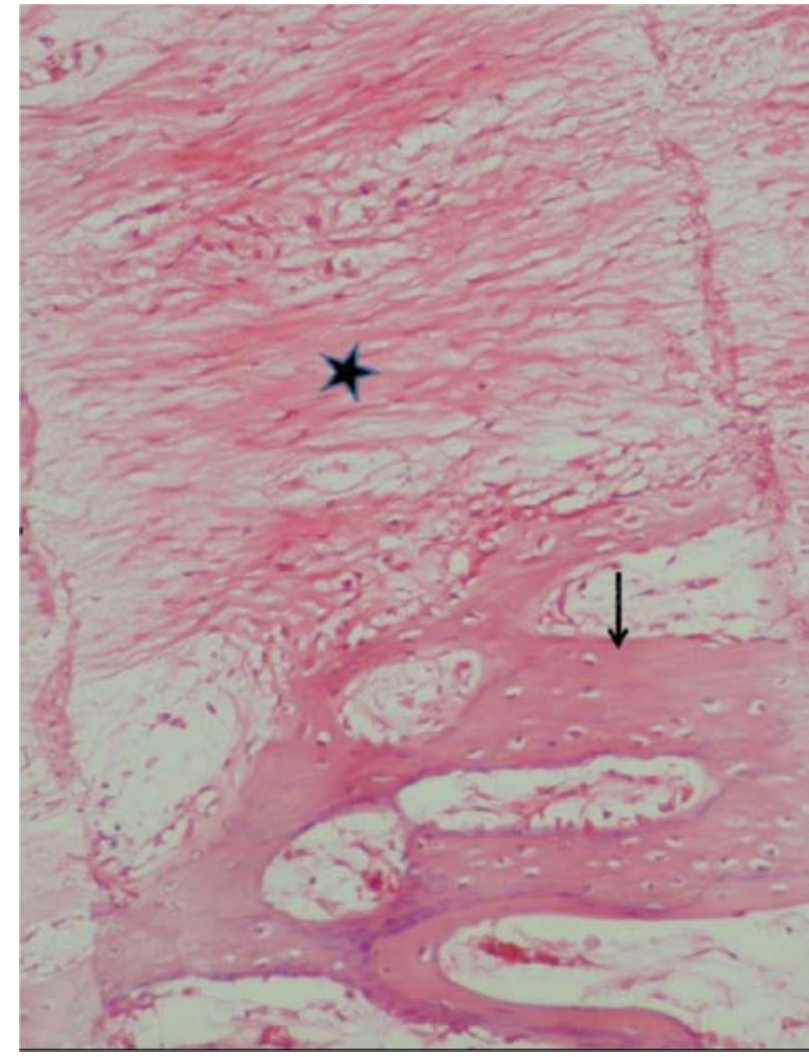

Figure 3. CG, ligament cells along the fracture healing line (star) and cartilage cells (arrow) healing score: 3 (x10, Haematoxylin-Eosin)

were observed in the CG samples (Figure 3), and immature bone tissues composed of chondrocytes and chondroblasts were dominant in the ZAG samples (Figure 4). As a result of the microscopic scorings, the difference between the two groups was found to be statistically significant $(\mathrm{p}<0.001)$ (Table 5).

\section{DISCUSSION}

In this study of the effect of zoledronic acid, which is commonly used in the treatment of osteoporosis, the results showed a positive effect of the adminis-

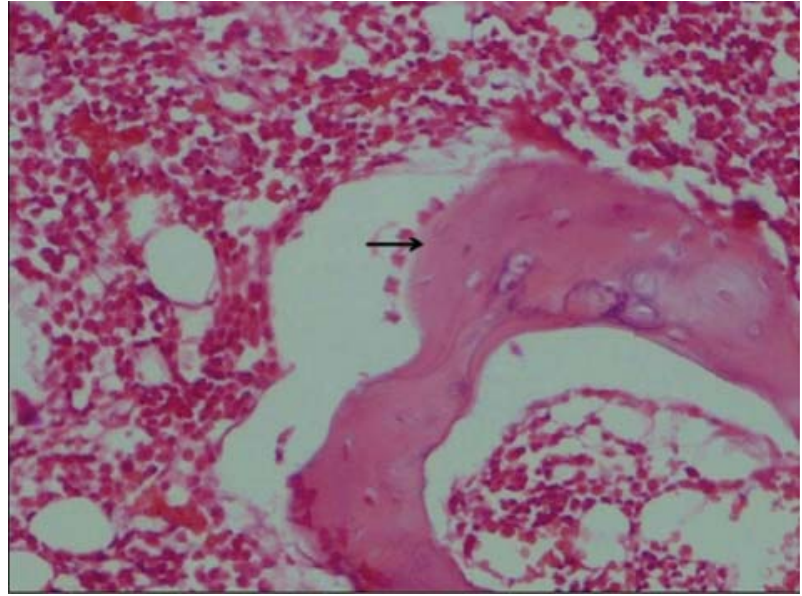

Figure 4. ZAG, Arrow showing the formation of immature bone in the fracture healing line. Healing score: 5 (x 20, Haematoxylin-Eosin)

tration of a single-dose on experimentally produced osteoporotic fractures in a rabbit model.

There is a complex relationship between osteoporosis and bone healing. Although available clinical evidence is insufficient, the slowing down of bone metabolism has been considered to be responsible for the delayed maturity of callus and the slowdown in bone healing (6). A review of the literature shows that in general the effects of bisphosphonates on bone healing in animal models are controversial. While some studies have stated that bisphosphonates delay and decrease callus formation but do not affect bone healing quality (10, 11), others have reported an increase in the amount of callus on the fracture line and accordingly, an improvement in fracture resistance (12). Still other experimental studies have shown that although ZA administration increases callus volume and improves mechanical endurance in the callus area, it causes delays on normal bone healing $(2,3,4)$. With currently gradually increasing use in the treatment of osteoporosis, the effect of ZA on bone healing following fracture in osteoporotic patients is not yet exactly known. In experimental stud-

Table 5. Histological healing scores pertaining to control and zoledronic acid groups

\begin{tabular}{|c|c|c|c|c|}
\hline \multirow{2}{*}{ Rabbit } & \multicolumn{2}{|c|}{ Control Group } & \multicolumn{2}{c|}{ Zoledronic acid Group } \\
\cline { 2 - 5 } & $\begin{array}{c}\text { Macroscopic } \\
\text { Appearance }\end{array}$ & $\begin{array}{c}\text { Microscopic } \\
\text { score }\end{array}$ & $\begin{array}{c}\text { Macroscopic } \\
\text { appearance }\end{array}$ & $\begin{array}{c}\text { Macroscopic } \\
\text { score }\end{array}$ \\
\hline 1 & Midpoint & 3 & Distal 1/3 & 5 \\
2 & Distal 1/3 & 3 & Distal 1/3 & 7 \\
3 & Midpoint & 3 & Distal 1/3 & 4 \\
4 & No callus & 3 & Midpoint & 5 \\
5 & Distal 1/3 & 3 & Distal 1/3 & 5 \\
6 & Midpoint & 3 & Proximal 1/3 & 5 \\
7 & - & - & Midpoint & 4 \\
\hline Median & & $\mathbf{3 , 0 0}$ & & $\mathbf{5 , 0 0} \mathrm{p}<0,001$ \\
\hline
\end{tabular}


ies, methods such as bilateral ovariectomy applications, low calcium diets along with ovariectomy, corticosteroid administrations following ovariectomy, denervation of the local skeletal area, gravity-free environment and stabilization of the bone with different techniques are used for the production of osteoporotic animal models $(13,14,15)$. In the current study, all the animals were ovariectomized bilaterally to produce experimental osteoporosis. Prior to the ovariectomy, the BMD of all the rabbits was measured and recorded. In studies carried out to produce experimental osteoporosis in literature, rabbit bones have been examined in biomechanical and densitometrical aspects after bilateral ovariectomy and osteoporotic changes have been observed to occur in at the end of 6-8 weeks $(13,16)$. In a study by Baofeng et al., it was stated that human osteoporosis is defined as a decrease of $>2.5$ standard deviation (SD), which corresponds to an approximate $25 \%$ fall in BMD. At the end of week 10 in that study, a 36\% decrease was observed in the BMD of the rabbits which had been applied with ovariectomy and methylprednisolone (15). Similarly, in the current study, a 10-week period was waited for the development of osteoporosis following ovariectomy in rabbits. BMD was measured again in all the rabbits and the values were compared to the preoperative values. A $28 \%$ fall was observed in the bone mineral densities after the ovariectomy in comparison with the previous values. This difference between the two measurements was also found to be statistically significant $(\mathrm{p}<0,001)$.

In a study that examined the effects of bisphosphonates on fracture healing, Madsen et al. produced closed fracture models in rat tibias by giving the subjects clodronate and no significant difference was seen in the amount of callus and bone bridging along the fracture line in the direct radiographic assessments carried out in the $4^{\text {th }}$ week of fracture healing (10). It was stated that this could have been due to the short healing period of 4 weeks. In another study, Tarvainen et al. examined the effect of clodronate on fracture healing in osteopenic and normal rats $(15,17)$. Callus endurance was not determined to be affected by drug administration in the osteopenic group, but it decreased at the end of 8 weeks in the non-osteopenic group. With these findings, it was concluded that bisphosphonates could have different effects on the healing of normal and osteopenic fractures. Accordingly, in the current study, which aimed to examine the effects of ZA on osteoporotic fracture healing, the periosteal reactions in the area of union, the bone healing findings and remodeling were based on the radiological evaluation of healing. Union was present in all 13 of the preparates included in the evaluations. In the analysis of the direct radiographs, it was concluded that remodelling was better in the area of the fracture in the ZAG samples and that bone union was better in this group since more periosteal reactions were present along the fracture line. The ZAG scores were higher than those of the CG and the averages were also higher. That the scorings were applied by two different observers also strengthened this argument. However, these findings were not found to be statistically significant $(\mathrm{p}=0.073)$.

In the assessment of the biomechanical test results of the study, no statistically significant difference was found between the analyses of the samples of ZAG and $\mathrm{CG}(\mathrm{p}=0.086)$. However, the finding that the amount of collapse was lower and the values of rigidity were higher in the ZAG samples suggested that the resistance in this group was higher than the samples in the control group and therefore ZAG was more resistant.

In a study by Y. Hao et al. ZA was applied to femur fractures of osteoporotic rabbit models on the postoperative $1^{\text {st }}$ day, $1^{\text {st }}$ week and $2^{\text {nd }}$ week and evaluations were made of bone healing (18). As a result of biomechanical tests, the strongest group was found to be the one that had been given the drug on the $1^{\text {st }}$ day while the least strong group was the drug-free control group. The biomechanical findings of the current study are compatible with the related literature, and ZA administration was shown to have a positive effect in biomechanical terms. However, although the elastic collapse and rigidity values of ZAG were found to be higher in the analyses, the differences between the groups were not statistically significant $(\mathrm{p}=0.086)$. Histological evaluation of fracture healing was applied according to the histological healing scale developed by Huo et al (9). According to the evaluation results, fibrous tissue, cartilage tissue, immature (woven) bone and mature (lamellar) bone were found in the section examined and the preparates were assessed based on the amounts. Although partial cartilage tissue and newly formed capillary veins were present in the callus tissue of the CG samples, the fact that fibrous tissue was much more prevalent in comparison to ZAG samples, and that cartilage tissue, mature and immature bone tissues were relatively less indicated that less microscopic healing occurred in the control group. Based on these findings, the healing scores were higher in ZAG and the difference between the groups was found to be statistically significant $(p<0.001)$. In another study which examined the effects of ZA on osteoporotic rat models following ovariectomy, it was found that ZA inhibited excessive bone resorption, and increased callus development and mineralization, although it prevented endochondral and fibrocartilage callus from developing into immature bone (18). In yet another study in which the effect of alendronatewas evaluated on fracture healing in dogs, it was observed that bone formation was 
not affected in the alendronate group while the amount of callus formation was twice or three times higher compared with the control group (19).

Limitations of the current study can be said to be that radiological evaluations were applied with a subjective assessment scale rather than an objective assessment method such as Micro CT, and that biomechanical tests were applied to only 8 of the 13 animals. This was because of concerns that samples required for the histological examinations might have been damaged.

\section{CONCLUSION}

According to the findings obtained from this study, in histological assessment of bone healing in ZAG and CG, better healing was observed in ZAG and the data were found to be statistically significant. However, although ZAG values were higher in mechanical and radiological evaluation, there was no statistically significant difference between the two groups. On the basis of these data, zoledronic acid administration can be considered to have a positive effect on fracture heal- ing in osteoporotic fractures. Conflicting results in the related literature can be attributed to the differences in subject types examined, the variety of drugs used, methods of drug injection, drug amounts and differences in timing.
Abbreviations
ZA - zoledronic acid
BMD - Bone mineral density
ZAG - zoledronic acid group
CG - control group

\section{DECLARATION OF INTEREST}

The authors declare that there are no conflicts of interest.

\section{Licensing}

This work is licensed under a Creative Commons Attribution 4.0 International (CC BY 4.0) License.

\title{
Sažetak
}

\section{PRIMENA ZOLEDRONIČNE KISELINE UNAPREĐUJE ZARASTANJE OSTEOPOROTIČNIH FRAKTURA KOD OVARIJEKTOMISANIH ZEČEVA}

\author{
Cansabuncu Gokhan, ${ }^{1}$ Sahin Namık, ${ }^{2}$ Akalin Yavuz, ${ }^{3}$ Cevik Nazan, ${ }^{3}$ Ozkaya Guven ${ }^{4}$ \\ ${ }^{1}$ Bartın State Hospital, Department of Orthopedics and Traumatology, Bart2n, Turkey \\ ${ }^{2}$ Konya Research and Training Hospital, Department of Orthopedics and Traumatology, Konya, Turkey \\ ${ }^{3}$ Bursa High Research and Training Hospital, Department of Orthopedics and Traumatology Yildirim, Bursa, Turkey \\ ${ }^{4}$ Medical Faculty of Uludağ University, Bursa, Turkey
}

Cilj: Evaluacija radioloških, histoloških i mehaničkih efekata primene mono-doze zoledronične kiseline na zarastanje osteoporotičnih fraktura kod životinja kod kojih je eksperimentalno izazvana osteoporotična fraktura kosti.

Metode: Ukupno 14 odraslih, zečeva ženki sa Novog Zelanda, starosti 5-6 meseci, je ispitivano u studiji. Mineralna gustina kosti (BMD) je određivana densiometrijom i memorisana. Potom je izvršena obostrana ovariektomija kod svih zečica. Desete nedelje nakon ovariektomije je ponovo urađena densiometrija kod svih zečica $i$ BMD je poređena. Osteoporosa je potvrđena kod životinja kod kojih je došlo do redukcije od 28\% u BMD vrednostima. Nakon plasiranja K-žice intramedularno u femur zečica, bliska fraktura je izazvana standardnom metodom. Životinje su potom nasumično podeljene u 2 grupe: zolendroična kiselina grupu (ZAG) i kontrolna grupa (CG). Infuzija od $0,1 \mathrm{mg} / \mathrm{kg}$ zolandreične kiseline je data ZAG životinjama kroz ušnu venu. Nakon što su životinje dekapitirane, radiloške i mehaničke procene su izvedene.
Rezultati: U histološkoj evaluaciji, srednji histološki skor je bio 5.0 u ZAG grupi i 3,0 u CG grupi. Razlike među grupama su statistički značajne $(\mathrm{p}<0,001)$. $\mathrm{U}$ radiološkoj evaluaciji srednja vrednost je bila 7,00 u ZAG i 6,25 u CG grupi. Iako je ZAG grupa dobila više bodova tokom evaluacije, razlika između grupa nije bila statistički značajna $(p=0,073)$. U mehaničkoj evaluaciji kolaps elastičnosti u negativnoj proporciji sa krutošću je izmeren i to 2,91 mm u ZAG i 3,96 mm u CG grupi $(p=0,686)$. Podaci o rigidnosti ZAG su bili viši u mehaničkim testovima, ali razlika između grupa nije bila statistički značajna $(\mathrm{p}=0,086)$.

Zaključak: Kako su rezultati studije pokazali da ZAG ima veće vrednosti od CG u svim histološkim, mehaničkim i radiološkim procenama, može se smatrati da primena jedne doze ZA povećava zarastanje osteoporotskih fraktura.

Ključne reči: zarastanje kostiju, osteoporoza, ovarijektomija, zolendronična kiselina, životinjski model. 


\section{REFERENCES}

1. Li EC, Davis LE. Zoledronic acid: A new parenteral bisphosphonate. Clin Ther. 2003; 25(11): 2669-708.

2. McDonald M, Dulai S, Godfrey C, Amanat N, Sztynda T, Little DG. Bolus or weekly zoledronic acid administration does not delay endochondral fracture repair but weekly dosing enhances delays in hard callus remodeling. Bone. 2008; 43(4): 653-62.

3. Matos MA, Arao FP, Paix FB. The effect of zoledronate on bone remodeling during the healing process. Acta Cirurgica Brasileira. 2007; 22(2): 115-9.

4. Amanat N, McDonald M, Godfrey C, Bilston L, Little D. Optimal timing of a single dose of zoledronic acid to increase strength in rat fracture repair. J Bone Minel Res. 2007; 22(6): 867-76.

5. Sambrook P, Cooper C. Osteoporosis. Lancet. 2006; 367(9527): 2010-18.

6. Giannoudis P, Tzioupis C, Almalki T, Buckley R. Fracture healing in osteoporotic fractures: is it really different? A basic science perspective. Injury. 2007; 38(suppl 1): S90-9.

7. Bonnarens F, Einhorn TA. Production of a standard closed fracture in laboratory animal bone. J Orthop Res. 1984; 2(1): 97-101.

8. An YH, Friedman RJ, Draughn RA. Animal models for bone Fracture or osteotomy. In An YH, Friedman RJ. Animal Models in Orthopaedic research. PA; CRC press 1999; 208.

9. Huo MH, Troiano NW, Pelker RR, Gundberg CM, Friedlaender GE. The influence of ibuprofen on fracture repair: biomechanical, biochemical, histologic, and histomorphometric parameters in rats. J Orthop Res. 1991; 9(3): 383-90.

10. Madsen JE, Berg-larsen T, Kirkeby OJ, Falch JA, Nordsletten L. No adverse effects of clodronate on fracture healing in rats. Acta Orthop Scand. 1998; 69(5): 532-6.
11. Koivukangas A, Tuukkanen J, Kippo K, Jämsä T, Hannuniemi R, Pasanen I et al. Long-term administration of clodronate does not prevent fracture healing in rats. Clin Orthop Relat Res. 2003; 408: 268-78.

12. Li J, Mori S, Kaji Y, Kawanishi J, Akiyama T, Norimatsu H. Concentration of bisphosphonate (incadronate) in callus area and its effects on fracture healing in rats. J Bone Min Res. 2000; 15(10): 2042-51.

13. Sevil F, Kara ME. The effects of ovariectomy on bone mineral density, geometrical, and biomechanical characteristics in the rabbit femur. Vet Comp Orthop Traum. 2010; 23(1): 31-6.

14. Castada S, Calvo E, Largo R, Gonzez-Gonzez R, de la Piedra C, Diaz-Curiel M et al. Characterization of a new experimental model of osteoporosis in rabbits. J Bone Miner Metab. 2008; 26(1), 53-9.

15. Baofeng L, Zhi Y, Bei C, Guolin M, Qingshui Y, Jian L. Characterization of a rabbit osteoporosis model induced by ovariectomy and glucocorticoid. Acta Orthop. 2010; 81(3): 396-401.

16. Arslan H, Ketani A, Gezici A, Kapukaya A, Necmioglu S, Kesemenli C et al. The effects of osteoporosis on distraction osteogenesis: an experimental study in an ovariectomised rabbit model. Acta Orthop Belq. 2003; 69(1): 67-73.

17. Tarvainen R, Olkkonen H, Nevalainen T, Hyven P, Arnala I, Alhava E. Effect of clodronate on fracture healing in denervated rats. Bone. 1994; 15(6): 701-5.

18. Hao Y, Wang X, Wang L, Lu Y, Mao Z, Ge S et al. Zoledronic acid suppresses callus remodeling but enhances callus strength in an osteoporotic rat model of fracture healing. Bone. 2015; 81: 702-11.

19. Peter CP, Cook WO, Nunamaker DM, Provost MT, Seedor JG, Rodan GA. Effect of alendronate on fracture healing and bone remodeling in dogs. J Orthop Res 1996; 14(1): 74-9.

\section{Correspondence to/Autor za korespondenciju}

Gökhan CANSABUNCU

Bartın State Hospital, Department of Orthopedics and Traumatology

Tuna mahallesi Kanlırmakcaddesi No: 73 Bartın, Turkey

Tel: +905333466965 